\title{
The Impact of Absorptive Capacity on Innovation in Peru
}

\author{
Luis Camilo Ortigueira-Sánchez', William C. Stein ${ }^{2}$, Santiago Luis Risco-Martínez $z^{3}$, María Fernanda Ricalde ${ }^{4 *}$
}

\begin{abstract}
This research aims to determine absorptive capacity's impact on innovation in SMEs in Peru. SMEs in Latin America tend to be characterized by technological backwardness, and innovations, if any, tend to be incremental in nature. In Peru, more than half of innovation activities are destined to the acquisition of capital goods. In this sense, rather than generate innovation, SMEs tend to adopt existing innovations. Thus, in order to reap the benefits of innovation adoption, SMEs must possess a high degree of absorptive capacity, understood as the firm's capacity to value external knowledge, assimilate, and exploit it towards commercial ends. In this respect, Innovate Peru, an innovation agency, grants subsidies to SMEs for facilitating innovation adoption. In collaboration between the public and academic sector, data was recollected from 88 SMEs that were granted this innovation subsidy. This paper contributes to the literature on absorptive capacity and innovation within Latin America, which has been vaguely studied. Likewise, it holds practical implications for top managers from SMEs who are looking to innovative, and policy implications for innovation policy makers, as it validates the effect of an innovation policy instrument.
\end{abstract}

Keywords: Absorptive capacity; Innovation; Innovation agency; SMEs; Latin America

Submitted: July $15^{\text {th }}, 2020 /$ Approved: October $21^{\text {st }}, 2020$

\section{Introduction}

The OECD has recognized SMEs as an engine of inclusive and sustainable economic development, given their importance in employment, decent jobs, and reducing economic inequality, as well as promoting industrialization and innovation (OECD, 2017). In emerging economies, SMEs contribute to about $45 \%$ of total employment and about $33 \%$ of the GDP. In Peru, $99.50 \%$ of all enterprises are SMEs, and they contribute to about $31 \%$ of added value and $89 \%$ of employment in the private sector (Ministerio de la Producción, 2018). Given the critical mass of SMEs in Peru, they are a key pillar of economic development.

One of the mechanisms in which SMEs can contribute to economic development is through promoting innovation, as they are responsible for most radical innovations nowadays, as well as exploiting technological and commercial opportunities often overlooked by larger enterprises. However, in comparison to large firms, SMEs face a set of barriers, such as access to coalified human capital, access to knowledge, or to finance, which limits its growth opportunities and innovative cap

In terms of the state of innovation in Peru, according to the National Innovation Survey of 2018, 54.90\% of surveyed firms conducted innovation (Ministerio de la Producción, 2019). However, the two main innovation activities were the acquisition of capital goods (53.50\%) and the development or acquisition of software and databases (44.00\%). T internal R\&D, and only $5.30 \%$ of firms conduct external R\&D. Thus, most innovation efforts in Peru is mainly based on technology adoption.

This is consistent with innovation processes in Latin America. For example, firms within the region tend to have information organizational structures to carry out innovation, have a low ratio of innovation projects, invest less in innovation, and innovation tends to be based of adoption of technology or capital goods (Crespi \& Peirano, 2007). Moreover, Latin American firms tend to carry out process innovations that are adaptative and incremental in nature (Crespi \& Zuniga, 2012). With the aim of promoting technology adoption as a means to innovate, Peru's National Innovation Agency, Innovate Peru, conducts public tenders for technology adoption and diffusion, granting SMEs a direct subsidy for this purpose.

Due to the importance of technology adoption within the innovation process of SMEs in the region, it is important to improve knowledge regarding this process, with the aim of increasing firm competitiveness. Namely, innovation adoption is conceived as the adoption or assimilation of a product, service, production technique, structure or administrative system, created internally or acquired, and that is new for the adopting organization (Damanpour, 1991; Hameed, Counsell, \& Swift, 2012). Innovation is defined in the latest version of the Oslo Manual as:

"A business innovation is a new or improved product or business process (or combination thereof) that differs significantly from the firm's previous products or business processes and that has been introduced on the market or brought into use by the firm" (OECD \& Eurostat, 2018, p. 20)

Now, in order for the firm to reap the benefits of innovation adoption, it requires certain internal capabilities that allow it to take advantage of the new product, technology or practice, and thus generate a sustained competitive advantage. In this regard, according to the Resource-Based View of the firm (Penrose, 1959), the resources in the firm which are valuable, rare, inimitable and are exploited by the organization constitute the foundation of the firm's competitive advantage (Barney, 1991).

\footnotetext{
(1) Department of Business, Universidad del Pacífico, Lima, Peru

(2) Directorate of Innovation, Ministry of Production, Lima, Peru

(3) Research Center, Universidad del Pacífico, Lima, Peru

(4) Universidad del Pacífico, Lima, Peru

*Corresponding author: 1c.ortigueiras@up.edu.pe
}

ISSN: 0718-2724. (http://jotmi.org)

Journal of Technology Management \& Innovation @ Universidad Alberto Hurtado, Facultad de Economía y Negocios. 
Building upon the resource-based view, the ability to use external knowledge is a critical factor to innovation adoption, which would give a firm an advantage over competitors. This capacity has been defined in the literature as absorptive (absorption) capacity, and is defined in the seminal work of Cohen \& Levinthal (1990) as "the ability of a firm to recognize the value of new, external information, assimilate it, and apply it to commercial ends" (Cohen \& Levinthal, 1990, p. 128). These authors state that the absorption of external knowledge favors innovation effort.

Absorptive capacity is both a relevant and valid concept in emerging economies as firms tend to be relegated in innovation, and therefore must undergo technological catch-up processes to stay competitive (Petti, Tang, \& Margherita, 2019). However, there is a lack of studies that explore these concepts in the context of emerging economies (Wadho \& Chaudhry, 2018). In Latin America in particular, the literature has not studied the effect of technological capabilities (Heredia, Flores, Heredia, Arango, \& Medina, 2019). Nonetheless, one of the main papers in the region is that of Bittencourt \& Giglio (2013) that study absorptive capacities in Brazilian firms, finding that training activities and internal $R \& D$ are the main sources of absorptive capacity that impact innovation.

In this sense, this paper aims to contribute to the body of knowledge on innovation in Latin America, in this case, in Peru. Thus, the main aim of this paper is to determine the impact that absorptive capacity has on innovation, in the case of SMEs that have received a public subsidy to innovate.

The main contribution of this paper is that it studies the effect of absorptive capacity on innovation, which has not been particularly studied in Latin America. This, it is contributing to the innovation literature, in identifying the capacities that SMEs need in order to carry out innovation successfully. Likewise, this paper also holds practical implications, given the fact that by determining a direct relation between innovation and absorptive capacity, the later can be used as a mechanism for companies to improve their innovation efforts. Lastly, this study contributes to the innovation policies in Peru, given the fact that the unit of analysis was SMEs that received a public grant to innovate.

\section{Literature Review}

\subsection{Absorptive Capacity}

The resource-based view (RBV) is a useful theoretical field to understand the way in which competitive advantages are generated within the firm, due to the firm leveraging its resources and capabilities (Eisenhardt \& Martin, 2000). As a theoretical field, RBV has advanced and, complementarity, the knowledge-based view (KBV) of the firm has emerged, which states that knowledge is the main source of productivity and the foundation of generating economic income (Grant, 2013). In the KBV, the generation of value requires knowledge generating processes, knowledge acquisition activities, and its application within the firm. Thus, the KBV states that firm's capacities to identify and integrate knowledge creates competitive advantages
(Un C. , 2017). These capacities are heterogenous between companies, and the higher the knowledge-generating capacities, the greater the firm's competitive edge (Un \& Asakawa, 2015).

The theoretical framework explained above lays the foundations for explaining absorptive capacity. In line with the RBV and KBV, the firms capacity to make use of external knowledge is critical for the flow of innovation, and innovation leads to a competitive advantage. Absorptive capacity is defined as: "the ability of a firm to recognize the value of new, external information, assimilate it, and apply it to commercial ends" (Cohen \& Levinthal, 1990, p. 128). Absorptive capacity is vital to the innovation process, for example, for the identification of needs or market opportunities. Moreover, it allows firms to cope with market changes, and given its cumulative nature, through greater R\&D activities and expenditure, firm performance is improved (Todorova \& Durisin, 2007; Vega-Jurado, Gutiérrez-Gracia, \& Fernández-de-Lucio, 2008).

This original definition of Absorptive Capacity was reconceptualized by Zahra \& George (2002), who define it as: "A set of organizational routines and processes by which firms acquire, assimilate, transform and exploit knowledge to produce a dynamic organizational capability" (Zahra \& George, 2002, p. 186). From the definition, four dimensions can be identified. The first dimension, acquisition, refers to the company's ability to identify and acquire external knowledge that is critical to its operations. The second dimension, assimilation, denotes the company's routines and processes that allow it to analyse, process, interpret and understand the information obtained from external sources. Transformation refers to the company's ability to develop and refine routines and processes that facilitate the combination of existing internal knowledge with new knowledge acquired and assimilated. Finally, exploitation is based on routines and processes that allow the company to refine, extend and take advantage of existing competences, or create new competencies, by incorporating the new knowledge acquired and assimilated into its processes (Zahra \& George, 2002).

Additionally, Zahra \& George (2002) classify absorptive capacity into two groups, potential and realized absorptive capacity. The first group is made up of the dimensions of acquisition and assimilation, and its objective is to prepare the company to acquire and assimilate external knowledge. The second group, realized absorption capacity, encompasses the transformation and exploitation dimensions, and reflects the company's capacity to take advantage of the knowledge that has been absorbed (Zahra \& George, 2002). This distinction of absorptive capacity is important to reflect the separation between the identification of opportunities or external knowledge and the capacities necessary to internalize and exploit such knowledge (Saemundsson \& Candi, 2017). Finally, the authors point out that absorption capacity has three impacts: greater strategic flexibility, better performance, and higher levels of innovation.

Now, the concept of absorptive capacity is inherently abstract and tacit, which has generated ambiguity in relation to its measurement. Likewise, there has been a lack of empirical studies that 
measure absorptive capacity in a real-life context (Jiménez-Barrionuevo, García-Morales, \& Molina, 2011). In practice, absorptive capacity can be observed in processes relation to technological acquisition, intellectual property rights, or strategic alliance formation (Patterson \& Ambrosini, 2015). This concept has been widely applied to international technology transfer studies. Technology transfer constitutes the main one through which the organization improves its absorption capacity, since technology transfer implies acquisition, assimilation, transformation and exploitation of technology and knowledge (Van der Heiden, Pohl, Mansor, \& Van Genderen, 2016). However, technology transfer studies have not focused on SMEs as a unit of analysis, so there is a lack of knowledge of this process in smaller companies (Bengoa, Maseda, Iturralde, \& Aparicio, 2020).

\subsection{Innovation}

In terms of innovation types, the Oslo Manual recognizes two types of innovations, namely, product and process innovation. Their definition is described as:

"A product innovation is a new or improved good or service that differs significantly from the firm's previous goods or services and that has been introduced on the market. A business process innovation is a new or improved business process for one or more business functions that differs significantly from the firm's previous business processes and that has been brought into use by the firm" (OECD \& Eurostat, 2018, p. 21).

Based on this definition, innovation requires both invention and exploitation, in other words, a true innovation is achieved once the product or process has been commercialized or brought into use by the firm (Dewangan \& Godse, 2014; Dziallas \& Blind, 2019). Furthermore, as the definition states, the innovation must differ significantly from the firm's previous goods, services, or business processes, independently of the degree of novelty in the market. Thus, an innovation can be generated internally or adopted from external sources, as long as it is brings value to the adopting firm (Damanpour, 1991; Damanpour \& Wischnevsky, 2006). While the generation of innovation results in the introduction of a product, service or process that is new for the firm, the adoption of innovation results in the assimilation of a product, service, or process that is new to the adopting firm (Hameed, Counsell, \& Swift, 2012). In this regard, innovation adoption aims to improve efficiency and performance in the adopting firm (Damanpour \& Gopalakrishnan, 1998).

Innovation adoption consists of three phases: initiation (pre-adoption), decision to adopt, and implementation (post-adoption). The first encompasses the activities related to identifying business needs, acquiring external knowledge, and searching for possible solutions (Pichlak, 2016). The second phase is related to the decision to adopt an identified solution, through a through evaluation of the solution in strategic, financial and technological terms, as well as the allocation of resources (Damanpour \& Schneider, 2006). Lastly, the final phase englobes the activities related to adapting the innovation to the firm, preparing the firm for its proper use, and employee acceptance of the innovation (Hameed, Counsell, \& Swift, 2012). It is worth noting that the innovation adoption process is influenced by the internal and external factors, namely, risk aversion, experience, industry competition, human capital capacities, and acquisitive power (Unsworth, Sawang, Murray, Norman, \& Sorbello, 2012).

Based on the innovation adoption process, absorptive capacity is especially relevant, as this ability will ultimately determine the degree to which the firm will be able to acquire, assimilate, transform, and exploit external knowledge. Thus, absorptive capacity facilitates innovation adoption. Notably, SMEs tend to be innovation adoptions, usually through capital goods acquisitions (Prokop \& Stejskal, 2019). Indeed, firms with technological gaps tend to prioritize adaptation of existing technologies, before developing such technologies internally (Wu, Ma, \& Xu, 2009). These types of SMEs, with technological backwardness, are common in emerging economies, with is why absorptive capacity and innovation adoption are relevant in this context (Nagano, Stefanovitz, \& Vick, 2014).

Lastly, the study of innovation is relevant, as it is a mechanism in which firms can add value and achieve superior performance. A higher innovation expenditure is positively related to firm performance (Emodi, Murthy, Emodi, \& Emodi, 2017). This relation has also been found in emerging economies (Wadho \& Chaudhry, 2018). For example, innovation has been found to affect performance in Chile and Peru (Heredia Perez, Geldes, Kunc, \& Flores, 2018). Moreover, SMEs that have received innovation subsidies have been found to achieve superior firm performance (Basit, Kuhn, \& Ahmed, 2018).

\section{Methodology}

\subsection{Sample Description and Context}

With the aim of testing for a dependent relationship between innovation and absorptive capacity, data was recollected from Innovate Peru, the National Innovation Agency of Peru. Specifically, data was recollected from SMEs that were beneficiaries of the public tender named "Technological Mission". The aim of this public tender is "To finance Technological Missions aimed at obtaining information, knowledge, or business processes and practices that contribute or facilitate technological upgrading in firms" (Innóvate Perú, 2018). Through this public tender, a group of between 03 and 10 SMEs can visit foreign firms, technological parks or center, fairs, or research institute, with a maximum duration of six months and a subsidy of up to US\$30,000. Thus, this public tender grants subsidies to promote the acquisition and assimilation of external knowledge, to later be able to apply this knowledge to improve the SMEs performance.

SMEs were surveyed according to the recommendations of the Oslo Manual (OECD \& Eurostat, 2018), as well as the Bogotá Manual, to account for structural differences in the innovation process in Latin America, such as informal organizational structures, a weak national innovation system, and a higher degree of uncertainty (Jaramillo, Lugones, \& Salazar, 2001). Likewise, firms have a low ratio of innovation projects, low expenditure on innovation, and the fact that most innovation is based mainly on the acquisition of capital goods (Crespi \& Peirano, 2007). 
In total, 88 SMEs were surveyed, who were beneficiaries of a Technological Mission between 2014 and 2016. This sample size is in line with the literature on absorptive capacity and innovation. For example, Tseng et al. (2011) used a sample of 88 Taiwanese SMEs in the service sector, and Solis-Vasquez et al. (2017) studied absorptive capacity's effect on innovation in the petrochemical sector in Mexico, using a sample of 96 SMEs. Lastly, in analyzing Chile's Innovation Agency, CORFO, and reviewing its program for technology transfer and diffusion, similar to Technological Missions, a total sample of 88 SMEs were used (Rivero Salinas, 2011).

\subsection{Variable Definition}

All the variables used in this study have been sourced from the literature on absorptive capacity and innovation. Thus, theoretical validity can be assured. The variables used are described below.

\subsubsection{Dependent Variable}

Innovation: SMEs were asked to indicate on a five-point Likert scale, the impact of the technological mission on firm innovation. This variable measures the top manager's perception on the effect the technological mission has had on the SME's innovation. The use of a scale variable to measure innovation has been widely used in the literature (Fores \& Camison, 2011; Lau \& Lo, 2019; Liao, Fei, \& Chen, 2007; Solis Vázquez, García Fernández, \& Zerón Félix, 2017). Likewise, this variable will give insights into the impact absorptive capacity has over innovation, after having been a beneficiary of an innovation subsidy (Radas \& Anic, 2013).

\subsubsection{Independent Variable}

Acquisition of External Knowledge: This variable measures the process related to potential absorptive capacity. SMEs were asked to indicate on a five-point Likert scale, the degree to which external knowledge was acquired during the technological mission. Thus, this variable measures the perception of the degree to which the firm has been able to value, identify, acquire and assimilate external knowledge (Fores \& Camison, 2011). Lastly, this measure has been widely used in the literature (Fores \& Camison, 2011; Fosfuri \& Tribó, 2008; Kostopoulos, Papalexandris, Papachroni, \& Ioannou, 2011; Lau \& Lo, 2019; Lau \& Lo, 2015; Solis Vázquez, García Fernández, \& Zerón Félix, 2017; Scuotto, Del Giudice, \& Carayannis, 2017).

Internal $R \& D$ : Internal $R \& D$ is part of the realized absorptive capacity, an is a byproduct of the firms capacity to assimilate, transform and exploit external knowledge (Un C., 2017). This variable is dichotomous, and measures whether the SME conducted internal R\&D. Since Cohen \& Levinthal's (1990) seminal work, internal R\&D has been widely used as a measure of absorptive capacity (Arbussa \& Coenders, 2007; Bittencourt \& Giglio, 2013; Escribano, Fosfuri, \& Tribo, 2009; Kostopoulos, Papalexandris, Papachroni, \& Ioannou, 2011; Un C., 2017).

Employee Training: This variable is dichotomous, and measures whether the firm has executed employee training activities. Training is a measure of realized absorptive capacity. Training employees is relevant because it is through training that employees will have greater learning capacities and greater ability to integrate external knowledge to the firm (Un C. , 2017). This variable is widely used as a measure of absorptive capacity (Bittencourt \& Giglio, 2013; Escribano, Fosfuri, \& Tribo, 2009; Kostopoulos, Papalexandris, Papachroni, \& Ioannou, 2011; Nieto \& Quevedo, 2005).

Innovation subsidy: Innovation subsidy was measured on a five-point Likert scale, with relation to the SME's perception on the economic resources granted by Innovate Peru for the Technological Mission. In this sense, this variable measures the perception of effectiveness of the subsidy from the SMEs perspective. This variable is validated in the studies of impact of innovation subsidy on innovation (Basit, Kuhn, \& Ahmed, 2018; Hall, Lotti, \& Mairesse, 2009; López-Acevedo \& Tinajero-Bravo, 2013; Yao, Xu, Jiang, \& Zhang, 2015).

Control variables: In order to control for possible alternative explanations to the general results, two control variables were included. In line with past research, the control variables incorporated were firm size (divided between microenterprises and small and mediumsized enterprises) and age (number of years from founding) (Kohlbacher, Weitlaner, Hollosi, Grunwald, \& Grahsl, 2013; Jansen, Van Den Bosch, \& Volberda, 2006). Jansen et al. (2005) mention that as firms increase in size, they may have more resources to allocate for innovation activities, yet they may lack the flexibility to acquire and assimilate new external knowledge, which ultimately impacts on the measures of absorptive capacity. Likewise, in terms of age, the firm gains more cumulative experience, but may also have problems in keeping up with technological advances generated externally (Sorensen \& Stuart, 2000).

\subsection{Statistical Model Definition}

The objective of this paper is to evaluate the impact that absorptive capacity plays on innovation, in the case of SMEs. In this context, the aim is to test for a significant dependent relationship between the measures of absorptive capacity (knowledge acquisition, internal $\mathrm{R} \& \mathrm{D}$, and employee training) and innovation subsidy on firm innovation. Thus, the most appropriate statistical methodology is multiple regression analysis. In innovation studies, regression analysis is the most widely used statistical method (Dziallas \& Blind, 2019).

Multiple linear regression is a variable dependency technique which enables the understanding of a relationship between a dependent variable and two or more independent variables, as well as quantifying the dependent relationship between variables that have been previously justified in the literature (Hair, Black, Babin, \& Anderson, 2014). In terms of assumptions, the dependent variable must be continuous, there must not be a high degree of multicollinearity between independent variables, and the model should have a high predictive power. In terms of sample size, Hair et al. (2014) recommend a ratio of 15:1 cases per independent variable. Thus, in this paper, a minimum of 60 cases would be required, which is satisfactorily met. 


\section{Results}

4.1. Descriptive Statisticseading 2

A thorough characterization of the sample if provided in Table 1, in terms of firm size, location, sector, educational level and Technological Mission destination.

Table 1. Characterization of the Sample

\begin{tabular}{|c|c|c|}
\hline Characteristics & Number & $\%$ of the sample \\
\hline \multicolumn{3}{|c|}{ Size } \\
\hline Microenterprise & 42 & $47.73 \%$ \\
\hline Small firm & 33 & $37.50 \%$ \\
\hline \multicolumn{3}{|c|}{ Sector } \\
\hline Agriculture & 18 & $20.45 \%$ \\
\hline \multicolumn{3}{|c|}{ Location } \\
\hline Lima (Capital) & 52 & $59.09 \%$ \\
\hline Provinces & 36 & $40.91 \%$ \\
\hline \multicolumn{3}{|c|}{ Education Level } \\
\hline Secondary Education & 12 & $13.64 \%$ \\
\hline Europe & 40 & $45.45 \%$ \\
\hline North America & 14 & $15.91 \%$ \\
\hline South America & 15 & $17.05 \%$ \\
\hline
\end{tabular}

Source: Own Elaboration

The sample is mainly made up of micro and small enterprises, with medium-sized firms having a substantially lower proportion. In terms of economic sector, most SMEs pertain to the manufacturing sector, followed by services and agriculture. In terms of location, roughly $60 \%$ of the sample is composed of SMEs based in Lima, the largest cosmopolite city in Peru. In this sense, the degree of technological backwardness is greater in SMEs based in provinces than in Lima. Nonetheless, in terms of the top manager's educational level, it is mostly composed of managers with at least a bachelor's degree. This is important given the fact that the educational level is an enabling factor for innovation. Lastly, regarding the Technological Mission's destination, most were destined towards Europe, mainly countries such as Italy, Germany, and Spain; followed by Asia, which was virtually represented entirely by visits to China. In South America, missions to Brazil, Argentina and Colombia were the most frequent, and, lastly, North America was roughly composed of the United States.

\subsection{Model Results}

Table 2 provides the correlation matrix for the variables under analysis.

Table 2. Correlation Matrix and descriptive statistics

\begin{tabular}{|c|c|c|c|c|c|c|c|}
\hline Variables & 1 & 2 & 3 & 4 & 5 & 6 & 7 \\
\hline 1.Innovation & 1 & & & & & & \\
\hline 2.Acquisition of External Knowledge & $0.6408^{* * *}$ & 1 & & & & & \\
\hline 3.Internal R\&D & $0.3209^{* * *}$ & 0.1253 & 1 & & & & \\
\hline 4.Employee Training & $0.3838^{* * *}$ & $0.3157^{* * *}$ & 0.1064 & 1 & & & \\
\hline 5.Innovation Subsidy & $0.3311^{* * *}$ & $0.4241^{* * *}$ & 0.0223 & 0.1341 & 1 & & \\
\hline 6.Firm Age & -0.0785 & -0.1060 & -0.0947 & 0.0430 & 0.1747 & 1 & \\
\hline $\mathrm{SD}$ & 0.864 & 0.679 & 0.305 & 0.209 & 0.877 & 7.311 & 0.502 \\
\hline Minimum & 1 & 2 & 0 & 0 & 2 & 3 & 0 \\
\hline Maximum & 5 & 5 & 1 & 1 & 5 & 26 & 1 \\
\hline
\end{tabular}

Source: Own Elaboration, ${ }^{* * *}$ p-value $<0.01$ 
All of the independent variables related to absorptive capacity and innovation subsidy have a positive correlation at the 0.01 level with the dependent variable, which is preliminarily a good overall indicator of a positive degree of association. Nonetheless, there is no correlation observed between the independent variables of firm age and size. Moreover, positive correlations were found between external knowledge acquisition with employee training and innovation subsidy. Likewise, a positive correlation was found between firm age and firm size, at the 0.01 level of significance. Besides this, no other significant relations were found. In general terms, the correlation coefficients were low, and no coefficient was greater than the recommended cutoff value of 0.70 (Hair, Black, Babin, \& Anderson, 2014).
Considering the literature review and prior studies, the impact of absorptive capacity on innovation was tested through five models. Model $1(n=85)$ uses the three independent variables of absorptive capacity and the independent variable of innovation subsidy. Model 2 $(n=85)$ and Model $3(n=85)$ incorporates the independent variables of firm age and firm size, respectively. Lastly, Model $4(n=43)$ and Model $5(n=42)$ divides the sample into two groups, considering only small and medium-sized firms and microenterprises, respectively. To test for multicollinearity in the five models, the variance inflation factor (VIF) was calculated (Table 3).

Table 3. Variance Inflation Factor (VIF) Analysis

\begin{tabular}{|c|c|c|c|c|c|}
\hline Independent Variables & Model 1 & Model 2 & Model 3 & Model 4 & Model 5 \\
\hline Acquisition of External Knowledge & 1.36 & 1.40 & 1.38 & 1.51 & 1.27 \\
\hline Internal R\&D & 1.03 & 1.03 & 1.04 & 1.11 & 1.03 \\
\hline Innovation Subsidy & 1.22 & 1.28 & 1.28 & 1.29 & 1.25 \\
\hline Firm Age & & 1.07 & & & \\
\hline
\end{tabular}

Source: Own Elaboration

In terms of cut-off values for VIF, values below 10 are recommended (Myers, 1990). Nonetheless, in small samples, a cut-off value of 3 is advised (Hair, Black, Babin, \& Anderson, 2014). All the independent varia- bles have VIF values less than 1.50. Likewise, the highest mean VIF is in Model 4, of only 1.30. Therefore, the modes are free of multicollinearity. The results of the multiple regression analysis are provided in Table 4.

Table 4. Regression Models

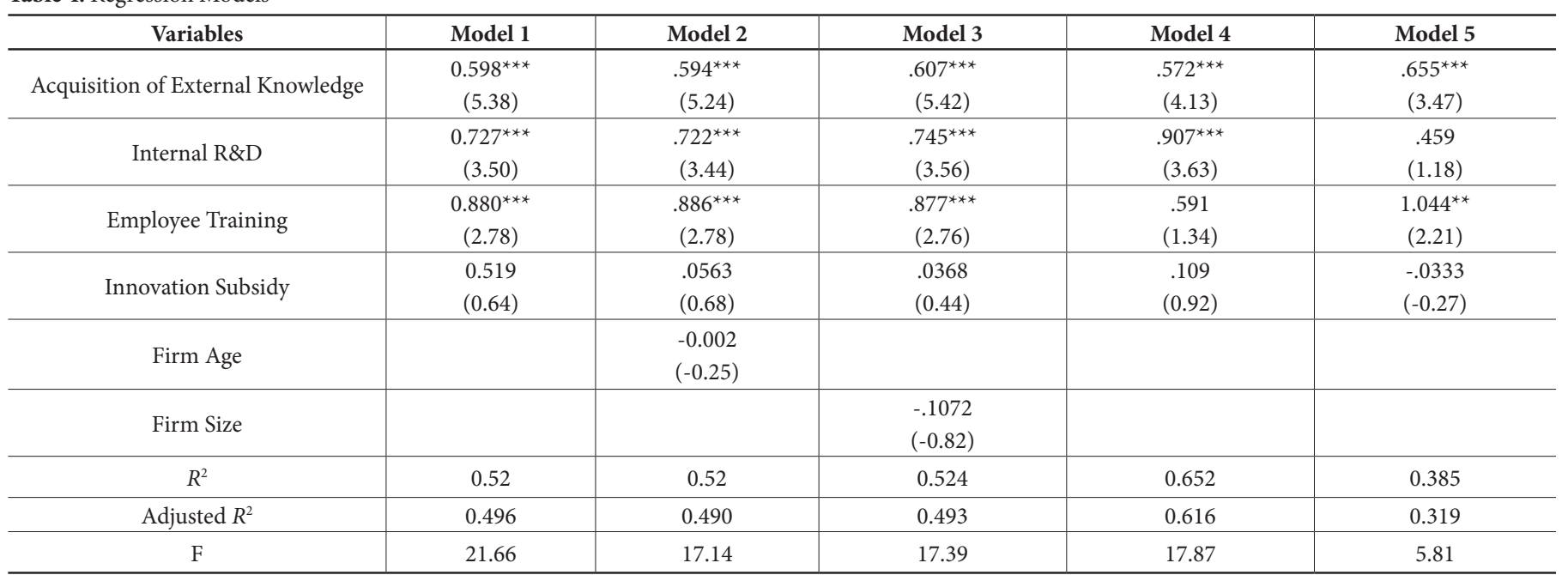

Source: Own Elaboration, ${ }^{* *} \mathrm{p}<0.01,{ }^{* *} \mathrm{p}<0.05$. Numbers in parenthesis are the $\mathrm{t}$-values

The F-statistic is positive throughout the five models, indicating a proper model fit. Likewise, to test for model reliability, the R-squared (R2) and adjusted R-squared coefficients were calculated. Transversally, the models present a large proportion of predictive power, being between the range of 0.385 and 0.652 , well above the threshold of a minimum R-squared value of 0.10 for exploratory studies (Falk \& Miller, 1992). Therefore, the model has an accepted model fit and a high reliability.
The baseline model (Model 1) indicates that innovation is dependent on the acquisition of external knowledge $(\beta=0.598, \mathrm{p}<0.01)$, internal R\&D $(\beta=0.7270, p<0.01)$, and employee training $(\beta=0.880, p$ $<0.01)$; however, a statistically significant relationship was not found between innovation subsidy and innovation, which is consistently found throughout the five models, indicating that innovation is not related to the innovation subsidy granted by Innovate Peru for the 
Technological Mission. Model 2 and Model 3 incorporate the control variables of firm age and firm size respectively. While in both models, the significance of the dimensions of absorptive capacity are maintained, there was not a statistically significant relationship between innovation and firm age or firm size. Thus, it can be affirmed that innovation is not dependent on the firm's age or size.

Furthermore, Model 4 tests the relationships solely using SMEs. In this case, the statistical significance is maintained in the variables of acquisition of external knowledge $(\beta=0.572, \mathrm{p}<0.01)$ and internal $\mathrm{R} \& \mathrm{D}(\beta=0.907, \mathrm{p}<0.01)$, while employee training's significance to innovation is not found. Therefore, using the sample composed of small and medium-sized enterprises, innovation is not dependent on employee training, and internal R\&D's contribution to innovation is notably increased. Lastly, regarding Model 5, which is composed of solely microenterprises, statistically significant relationships were observed in the case of acquisition of external knowledge ( $\beta=0.655$, $\mathrm{p}<0.01)$ and employee training $(\beta=1.044, \mathrm{p}<0.05)$, while internal R\&D's significance to innovation is not observed. In this model, innovation's dependence on employee training is notably increased.

\subsection{Discussion}

In the light of the results, a dependent relationship is found between innovation and absorptive capacity, which is in line with previous results (Cohen \& Levinthal, 1990; Kostopoulos, Papalexandris, Papachroni, \& Ioannou, 2011; Zahra \& George, 2002). MSMEs have been able to value, acquire and assimilate external knowledge; likewise, through innovation activities such as internal R\&D and employee training, MSMEs have a positive effect on innovation (Fores \& Camison, 2011; Scuotto, Del Giudice, \& Carayannis, 2017). Thus, by using Technological Missions, SMEs have been able to leverage their absorptive capacity, and this has ultimately had a positive result on innovation.

Furthermore, from the coefficient values in Model 1, Model 2 and Model 3, a result can be observed. Even though all of absorptive capacity's measure positively impacted innovation, the effect is much more pronounced in the case of realized absorptive capacity. An advantage of using a multidimensional view of absorptive capacity is that individual contributions to innovation can be identified. Thus, in the case of this paper, realized absorptive capacity (internal R\&D and employee training) has a higher impact on innovation than potential absorptive capacity (acquisition of external knowledge).

This heterogeneity in terms of impact is justified in the literature, and previous studies have similar findings (Lau \& Lo, 2019; Todorova \& Durisin, 2007). For example, albeit the fact that potential absorptive capacity is a necessary condition to innovate, firms require the ability to be able to transform and exploit this external knowledge (Fores \& Camison, 2011).

On the other hand, regarding Model 2 and 3, and the lack of a statistical relationship between innovation and firm age and firm size, our results are similar to those found by Kohlbacher et al. (2013), who incorporated these control variables in their study of absorptive capacity's effect on explorative and exploitative innovation, and did not find a significant relationship. Likewise, Jensen et al. (2006) did not find a significant relationship between size and age in the case of exploitative innovation. Therefore, these results are in line with previous empirical studies, and, thus, in our study, innovation is not dependent on either firm age or firm size.

Regarding Model 4 and 5, which measures the relationship between absorptive capacity and innovation in the case of SMEs and Microenterprises, respectively, results are mixed. The main difference between the models is that in Model 4, internal R\&D is statistically significant and employee training is not, while in Model 5, employee training is statistically significant and internal R\&D is not. Nonetheless, in either model, the statistical significance of acquisition of external knowledge is maintained. Thus, potential absorptive capacity impacts innovation in both cases, while results are mixed regarding realized potential absorptive capacity dimensions.

In their literature review, Mikhailov \& Reichert (2019) identify that some studies find mixed results in terms of absorptive capacity dimensions' effect over innovation, where some dimensions show no effect. Likewise, our results are similar to those found by Larrañeta et al. (2017), who find that in the case of new firms realized absorptive capacity negatively relates to performance, due to high costs of early absorptive capacity development and limited knowledge to capitalize on results. Based on our results, internal $R \& D$ requires cumulative experience and a solid knowledge base, which microenterprises, given their size and relatively young age, might lack. Therefore, microenterprises are reluctant to perform internal R\&D activities which is inherently a high risk endeavor, and tend to perform more low-risk activities such as employee training. In contrast, in SMEs, given their relatively superior resources and cumulative experience, their internal knowledge base is more solid, which enables them to perform more high-risk activities such as internal R\&D. In this case, training activities, as a dimension of realized absorptive capacity, do not have an impact on innovation. Similar results were found in Bittencourt \& Giglio's (2013) study of absorptive capacity in Brazilian firms.

Lastly, given the fact that a significant relationship between the public subsidy and innovation was not found, this could be explained in practical terms, due to the nature of the Technological Mission itself. The public tender is aimed solely to obtain information, knowledge, or business practices that facilitate technological upgrading (Innóvate Perú, 2018). Thus, it is aimed solely at acquisition and assimilation of external knowledge potential absorptive capacity, without regard to realized absorptive capacity. However, our findings indicate the it is realized absorptive capacity which ultimately impacts innovation. In this case, the lack of a dependent relationship can be explained.

Now, regarding the finding itself of an insignificant relationship between innovation subsidy and innovation, this contrasts the existing literature (Basit, Kuhn, \& Ahmed, 2018; Guo, Guo, \& Jiang, 2016). Nonetheless, most studies that analyze innovation subsidies are of empirical nature. Therefore, an insignificant impact of innovation subsidy has also been observed. For example, Koski \& Pajarinen 
(2013) find an insignificant relationship between innovation subsidy and innovation activities in Finnish SMEs; likewise, Gustafsson et al. (2016) state that there is no long-term effect between innovation subsidy and a superior firm performance.

\section{Conclusions}

The present research aimed at analyzing the impact absorptive capacity has on innovation, in the case of SMEs which were granted an innovation subsidy. Based on Cohen \& Levinthal's (1990) as well as Zahra \& George's (2002) conceptualization of absorptive capacity, this was tested on innovation, using regression analysis, which is the most common statistical method for innovation studies (Dziallas \& Blind, 2019). Through this regression, our results find a positive and statistically dependent relationship between absorptive capacity and innovation. However, a significant relationship between innovation subsidy, provided by Innovate Peru, and innovation was not found; thus, innovation is not dependent on the innovation subsidy in our study. Likewise, controlling for firm size and age, a statistical relationship was not found. Nonetheless, absorptive capacity's effect on innovation differs when dividing the sample into two groups, namely, microenterprises and small and medium-sized firms.

Considering our findings, this paper holds theoretical, practical, and political implications. First, having used Peruvian SMEs, this research has contributed to closing the theoretical understanding of innovation processes in Latin America (Heredia, Flores, Heredia, Arango, \& Medina, 2019). Likewise, being an empirical study, it contributes to the theoretical field of absorptive capacity, in which Jimenez-Barrionuevo et al. (2011) mention a need for empirical studies on the matter.

Second, this research holds practical implications for SME top management. Given the fact that a dependent relation was found between absorptive capacity and innovation, SMEs should allocate time and resources to improve their acquisition, assimilation, transformation and exploitation of external knowledge to the firm, as this will ultimately drive their innovation process, and later contribute to the formation of sustained competitive advantages. Furthermore, taking into consideration that the main innovation activity in Peru, as in most of Latin America, is the acquisition of capital goods, absorptive capacity plays a key role in the innovation adoption process, for firms to be able to truly reap the benefits of capital goods acquisitions.

Third, in terms of political implications, this study has used as a unit of analysis public tender-winning SMEs, that were granted an innovation subsidy. Given the lack of a significant relationship between innovation subsidy and innovation activities in the SME, the public tender Technological Missions has not had the desired effect on SMEs. Thus, our main implication is that this public tender requires reformulation, to englobe not only potential absorptive capacity, but also activities related to being able to transform and exploit the external knowledge for business purposes.

In terms of limitations, the study was composed of a relatively small sample size, which may ultimately affect the results. Nonetheless, there was a proper model fit and a high reliability. Also, given the fact that the sample was composed of beneficiary SMEs, the results generalization or extension to other contexts may be limited. In this regard, future lines of research could study a more integrative model, studying the relationship between absorptive capacity, innovation and firm performance. Likewise, they could test the relationship between absorptive capacity and innovation in the context of both beneficiary and non-beneficiary SMEs, to validate if indeed the innovation subsidy has an effect on absorptive capacity or innovation.

\section{References}

Arbussa, A., \& Coenders, G. (2007). Innovation activities, use of appropriation instruments and absorptive capacity: Evidence from Spanish firms. Research Policy, 36(10), 1545-1558.

Barney, J. (1991). Firm resources and sustained competitive advantage. Journal of Management, 17(1), 99-120.

Basit, S. A., Kuhn, T., \& Ahmed, M. (2018). The Effect of Government Subsidy on Non-Technological Innovation and Firm Performance in the Service Sector: Evidence from Germany. Business Systems Research, 9(1), 118-137.

Bengoa, A., Maseda, A., Iturralde, T., \& Aparicio, G. (2020). A bibliometric review of the technology transfer literature. The Journal of Technology Transfer, 1-37.

Bittencourt, P. F., \& Giglio, R. (2013). An empirical analysis of technology absorption capacity of the Brazilian industry. CEPAL Review(111), 175-190.

Cohen, W. M., \& Levinthal, D. A. (1990). Absorptive capacity: A new perspective on learning and innovation. Administrative Science Quarterly, 128-152.

Crespi, G., \& Peirano, F. (2007). Measuring innovation in Latin America: what we did, where we are and what we want to do. United Nations University and Maastricht Social and Economic Research and Training Institute on Innovation and Technology (UNU-MERIT) Conference on Micro Evidence on Innovation in Developing Countries, 31.

Crespi, G., \& Zuniga, P. (2012). Innovation and Productivity: evidence from six Latin American countries. World Development, 40(2), 273-290.

Damanpour, F. (1991). Organizational innovation: A meta-analysis of effects of determinants and moderators. Academy of Management Journal, 34(3), 555-590.

Damanpour, F., \& Gopalakrishnan, S. (1998). Theories of organizational structure and innovation adoption: the role of environmental change. Journal of Engineering and Technology Management, 15(1), 1-24.

Damanpour, F., \& Schneider, M. (2006). Phases of the adoption of innovation in organizations: effects of environment, organization and top managers. British Journal of Management, 17(3), 215-236. 
Damanpour, F., \& Wischnevsky, J. D. (2006). Research on innovation in organizations: Distinguishing innovation-generating from innovation-adopting organizations. Journal of Engineering and Technology Mangement, 23(4), 269-291.

Dewangan, V., \& Godse, M. (2014). Towards a holistic enterprise innovation performance measurement system. Technovation, 34(9), 536-545.

Dziallas, M., \& Blind, K. (2019). Innovation indicators throughout the innovation process: An extensive literature analysis. Technovation, 80, 3-29.

Eisenhardt, K. M., \& Martin, J. A. (2000). Dynamic capabilities: what are they? Strategic Management Journal, 21(10), 1105-1121.

Emodi, N. V., Murthy, G. P., Emodi, C. C., \& Emodi, A. S. (2017). Factors influencing innovation and industrial performance in Chinese manufacturing industry. International Journal of Innovation and Technology Management, 14(6), 1-32.

Escribano, A., Fosfuri, A., \& Tribo, J. A. (2009). Managing external knowledge flows: The moderating role of absorptive capacity. Research Policy, 38(1), 96-105.

Falk, R. F., \& Miller, N. B. (1992). A primer on soft modelling. Akron: University of Akron Press.

Fores, B., \& Camison, C. (2011). The complementary effect of internal learning capacity and absorptive capacity on performance: the mediating role of innovation capacity. International Journal of Technology Management, 55(1), 56-81.

Fosfuri, A., \& Tribó, J. A. (2008). Exploring the antecedents of potencial absorptive capacity and its impact on innovation performance. Omega, 36(2), 173-187.

Grant, R. M. (2013). Reflections on knowledge-based approaches to the organization of production. Journal of Management \& Governance, 17(3), 541-558.

Guo, D., Guo, Y., \& Jiang, K. (2016). Government-subsidized R\&D and firm innovation: evidence from China. Research Policy, 45(6), 1129-1144.

Gustafsson, A., Stephan, A., Hallman, A., \& Karlsson, N. (2016). The "sugar rush" from innovation subsidies: a robust political economy perspective. Empirica, 43, 729-756.

Hair, J. F., Black, W. C., Babin, B. J., \& Anderson, R. E. (2014). Multivariate Data Analysis (Vol. 6). London: Pearson New International Edition.

Hall, B. H., Lotti, F., \& Mairesse, J. (2009). Innovation and productivity in SMEs: empirical evidence for Italy. Small Business Economics, 33(1), 13-33.

Hameed, M. A., Counsell, S., \& Swift, S. (2012). A conceptual model for the process of IT innovation adoption in organizations. Journal of Engineering and Technology Management, 29(3), 258-390.
Heredia Perez, J., Geldes, C., Kunc, M., \& Flores, A. (2018). New approach to the innovation process in emerging economies: The manufacturing sector case in Chile and Peru. Technovation, 79, 35-55.

Heredia, J., Flores, A., Heredia, W., Arango, R., \& Medina, L. (2019). How Innovation Influences on Export Performance: A Configuration Approach for Emerging Economies. Journal of Technology Management \& Innovation, 14(4), 54-65.

Innóvate Perú. (Mayo de 2018). Bases Integradas del Concurso de Proyectos de Misiones Tecnológicas. Obtenido de https://innovateperu.gob. pe/fincyt/doc/misiones/2018/bases/C5/BASES\%20Integradas_Misiones\%20Tecnologicas\%20_\%20C5_110518.pdf?fbclid=IwAR1jbI9U0cxx tvojKq3ndnzMwngdZLUhYvYWX3jRIlTfmmXQJhXvVVnXp5I

Jansen, J. J., Van Den Bosch, F. A., \& Volberda, H. W. (2005). Managing potential absorptive capacity: how do organizational antecents matter? Academy of Management Journal, 48(6), 999-1015.

Jansen, J. J., Van Den Bosch, F. A., \& Volberda, H. W. (2006). Exploratory innovation, exploitative innovation and performance: Effects of organizational antecedents and environmental moderators. Management Science, 52(11), 1661-1674.

Jaramillo, H., Lugones, G., \& Salazar, M. (2001). Manual de Bogotá. Organización de Estados Americanos (OEA). Bogotá: Red Iberoamericana de Indicadores de Ciencia y Tecnología (RICYT).

Jiménez-Barrionuevo, M. M., García-Morales, V. J., \& Molina, L. M. (2011). Validation of an Instrument to Measure Absorptive Capacity. Technovation, 3(5), 190-202.

Kohlbacher, M., Weitlaner, D., Hollosi, A., Grunwald, S., \& Grahsl, H. P. (2013). Innovation in clusters: effects opf absorptive capacity and environmental moderators. Competitiveness Review: An International Business Journal, 23(3), 199-217.

Kolade, O., Obembe, D., \& Salia, S. (2019). Technological constraints to firm performance. Journal of Small Business and Enterprise Development, 1-40.

Koski, H., \& Pajarinen, M. (2013). The role of business subsidies in job creation of start-ups, gazelles and incumbents. Small Business Economics, 41(1), 195-214.

Kostopoulos, K., Papalexandris, A., Papachroni, M., \& Ioannou, G. (2011). Absorptive capacity, innovation, and financial performance. Journal of Business Research, 64(12), 1135-1343.

Larrañeta, B., González, J. L., \& Aguilar, R. (2017). Early efforts to develop absorptive capacity and their performance implications: Differences among corporate and independent ventures. The Journal of Technology Transfer, 42(3), 485-509.

Lau, A. K., \& Lo, W. (2015). Regional innovation system, absorptive capacity and innovation performance: An empirical study. Technological Forecasting and Social Change, 92, 99-114. 
Lau, A. K., \& Lo, W. (2019). Absorptive capacity, technological innovation capability, and innovation performance: an empirical study in Hong Kong. International Journal of Technology Management, 80(12), 107-148.

Liao, S. H., Fei, W. C., \& Chen, C. C. (2007). Knowledge sharing absorptive capacity and innovation capability: an empirical study of Taiwan's knowledge-intensive industries. Journal of Information Science, 33(3), 340-359.

López-Acevedo, G., \& Tinajero-Bravo, M. (2013). Evaluating Different Types of Enterprise Support Programs Using Panel Firm Data: Evidence from the Mexican Manufacturing Sector. Economía, 14(1), $1-26$.

Mikhailov, A., \& Reichert, F. M. (2019). Influence of absorptive capacity on innovation: A systemic literature review. Revista de Administração Mackenzie, 20(6), 1-27.

Ministerio de la Producción. (2018). Las MIPYME en Cifras 2017. Lima: Oficina General de Evaluación de Impacto y Estudios Económicos.

Ministerio de la Producción. (2019). Encuesta Nacional de Innovación en la Industria Manufacturera y de Servicios Intensivos en Conocimiento - ENIIMESIC 2018. Dirección General de Innovación, Tecnología, Digitalización y Formalización.

Myers, R. H. (1990). Classical and modern regression with applications. Boston: Duxbury.

Nagano, M. S., Stefanovitz, J. P., \& Vick, T. E. (2014). Innovation management processes, their internal organizational elements and contextual factors: An investigation in Brazil. Journal of Engineering and Technology Management, 33, 63-92.

Nieto, M., \& Quevedo, P. (2005). Absorptive capacity, technological opportunity, knowledge spillovers, and innovative effort. Technovation, 25(10), 1141-1157.

OECD \& Eurostat. (2018). Oslo Manual 2018: Guidelines for Collecting, Reporting and Using Data on Innovation (4th ed.). Paris: OECD Publishing.

OECD. (2017). Enhancing the Contributions of SMEs in a Global and Digitalised Economy. Paris: Meeting of the OECD Council at Ministerial Level.

Patterson, W., \& Ambrosini, V. (2015). Configuring absorptive capacity as a key process for research intensive firms. Technovation, 36, 77-89.

Penrose, E. (1959). The Theory of the Growth of the Firm. Oxford: Oxford University Press.

Petti, C., Tang, Y., \& Margherita, A. (2019). Technological innovation vs technological backwardness patterns in latecomer firms: An absorptive capacity perspective. Journal of Engineering and Technology Management(51), 10-20.
Pichlak, M. (2016). The innovation adoption process: A multidimensional approach. Journal of Management \& Organization, 22(4), 476-494.

Prokop, V., \& Stejskal, J. (2019). Determinants of innovation activities and SME absorption - Case study of Germany. Scientific Papers of the University of Pardubice, 46, 134-146.

Radas, S., \& Anic, I. D. (2013). Evaluating additionality of an innovation subsidy program targeted at SMEs: An exploratory study. Croatian Economic Survey, 15, 61-88.

Rivero Salinas, D. A. (2011). Evaluación de Resultados "Programa de Difusión y Transferencia Tecnológica. Santiago de Chile: Universidad de Chile.

Saemundsson, R. J., \& Candi, M. (2017). Absorptive capacity and the identification of opportunities in new technology-based firms. Technovation, 64, 43-49.

Scuotto, V., Del Giudice, M., \& Carayannis, E. G. (2017). The effect of social networking sites and absorptive capacity on SMEs' innovation performance. The Journal of Technology Transfer, 42(2), 409-424.

Solis Vázquez, S. Y., García Fernández, F., \& Zerón Félix, M. (2017). Impacto de la capacidad de absorción del conocimiento en la innovación: El caso del sector petroquímico en Reynosa, México. Innovar: Revista de Ciencias Administrativas y Sociales, 27(66), 11-27.

Sorensen, J. B., \& Stuart, T. E. (2000). Aging, obsolescence, and organizational innovation. Administrative Science Quarterly, 45(1), 81-112.

Todorova, G., \& Durisin, B. (2007). Absorptive capacity: Valuing a reconceptualization. Academy of Management Review, 32(3), 774-786.

Tseng, C., Chang Pai, D., \& Hung, C. (2011). Knowledge absorptive capacity and innovation performance in KIBs. Journal of Knowledge Management, 15(6), 971-983.

Un, C. (2017). Absorptive capacity and R\&D outsourcing. Journal of Engineering and Technology Management, 43, 34-47.

Un, C., \& Asakawa, K. (2015). Types of R\&D collaborations and process innovations: The benefit of collaborating upstream in the knowledge chain. Journal of Production Innovation Management, $32(1), 138-153$.

Unsworth, K., Sawang, S., Murray, J., Norman, P., \& Sorbello, T. (2012). Effects of orientation, pressure, and control on adoption intentions. International Journal of Innovation Management, 16(1), 1-35.

Van der Heiden, P., Pohl, C., Mansor, S., \& Van Genderen, J. (2016). Necessitated absorptive capacity and metaroutines in international technology transfer: A new model. Journal of Engineering and Technology Management, 41, 65-78.

Vega-Jurado, J., Gutiérrez-Gracia, A., \& Fernández-de-Lucio, I. (2008). Analyzing the determinants of firm's absorptive capacity: beyond R\&D. R\&D Management, 38(4), 392-405. 
Wadho, W., \& Chaudhry, A. (2018). Innovation and firm performance in developing countries: The case of Pakistani textile and apparel manufacturers. Research Policy, 47(7), 1283-1294.

Wu, X., Ma, R., \& Xu, G. (2009). Accelerating secondary innovation through organizational learning: A case study and theoretical analysis. Industry and Innovation, 16(4), 389-409.
Yao, Q., Xu, M., Jiang, W., \& Zhang, Y. (2015). Do marketing and government R\&D subsidy support technological innovation? International Journal of Technology, Policy and Management, 15(3), 213 225.

Zahra, S. A., \& George, G. (2002). Absorptive capacity: A review, reconceptualization, and extension. Academy of Management Review, 27(2), 185-203. 